\title{
Renewable energy sources and Turkey
}

\author{
Ali Vardar, Onur Taskin \\ Uludag University, Faculty of Agriculture, Department of Biosystems Engineering, Nilufer, 16059 Bursa, Turkey
}

Email address:

dravardar@uludag.edu.tr(A.Vardar),onurtaskins@gmail.com (O. Taskin)

\section{To cite this article:}

Ali Vardar, Onur Taskin. Renewable Energy Sources and Turkey. International Journal of Energy and Power Engineering.

Vol. 3, No. 5, 2014, pp. 245-249. doi: 10.11648/j.ijepe.20140305.14

\begin{abstract}
International economic competition is forcing countries for improving their technology. The main elements are knowledge and R\&D for countries technological developments. However, the impulsion of development is "energy". In this context, energy consumption is a one of the pointer for determine to development level of a country. Renewable energies are main sources of our energy consumption; the amounts of finite energy sources are decreasing so that countries are choosing renewable energy, especially in last 10-15 years. In this frame, renewable energy sources will have important potential for energy consumption in a near future. Renewable energy sources have huge advantages, such as not harming the environment, no risk on running out, able to produce with local resources on micro level, less dependency to out, without problem of supply-transport and demand security. In this study, renewable energy sources are firstly review on globally and also particularly Turkey taken in hand for potential analysis of natural energy. In this case, requirement is a new "strategy and policy of energy diversification".
\end{abstract}

Keywords: Energy, Renewable Energy, Energy Sources, Turkey

\section{Introduction}

The renewable energy resources that are created as a result of transforming solar energy, are both the oldest and the most modern and cleanest energy sources that were or are used by mankind. [1]. The technologies that utilize solar, wood, water and wind powers had always kept their development process since the first years of the industrial revolution. But along with the industrial revolution, coal and fossil fuels found a wide usage area for themselves and due to their abundance, they had a major advantage compared with the other energy resources. As a result of these developments, coal and fossil fuels replaced wood, water and wind energy resources especially in transportation, industry and in households. In our day, coal, oil and natural gas comprise the three fundamental energy sources in the world.

Besides reasons such as air pollution, accidents occurring during mining activities and the limited natural resources, concerns about the environmental and social outcomes of fossil fuel utilization have been ongoing for centuries [1]. But it was not possible to prevent the increase in fossil fuel utilization. Yet the extreme increase in oil prices during the crisis in the 1970's and intensified emergence of environmental effects have been an important warning. During this period, people began to take more seriously the depletion possibility of fossil fuels or the possibility that the biological and environmental system and global climate balance may be disrupted in case of continuing to use fossil fuels.

Continuation of the concerns regarding the sustainability of using fossil and nuclear fuels in our day makes the renewable energy resources a recurring and more important item in the agenda in the last decade. An ideal and sustainable energy resource should have continuous usage and renewable qualities, should not pollute the environment or cause any other environmental problems and should not create social injustice or health threats [2]. Renewable energy resources largely carry these qualities that are attributed to this ideal and sustainable energy resource.

Uninterrupted, reliable, clean and cheap procurement and diversification of energy as one of the most fundamental requirements of economic and social development drivers for countries carries great importance [2]. At this point, the most realistic and prioritized energy resources that may come into play are renewable energy sources. Just as the $19^{\text {th }}$ century was the century of coal and $20^{\text {th }}$ century was the century of oil, it will not be an exaggerated estimate to say that $21^{\text {st }}$ century will be the century of solar and wind (renewable energies). 


\section{Renewable Energy Resources}

Renewable energy can be defined as "energy obtained from sources arising in the natural environment that are derived from continuous or renewing resources (powers)" [3] or "energy flows that are replaced as they are used" [4]. Figure 1 summarizes the renewable energy resource origins of the world and their extent, and it can be clearly seen that solar radiation is the main source of renewable energies.

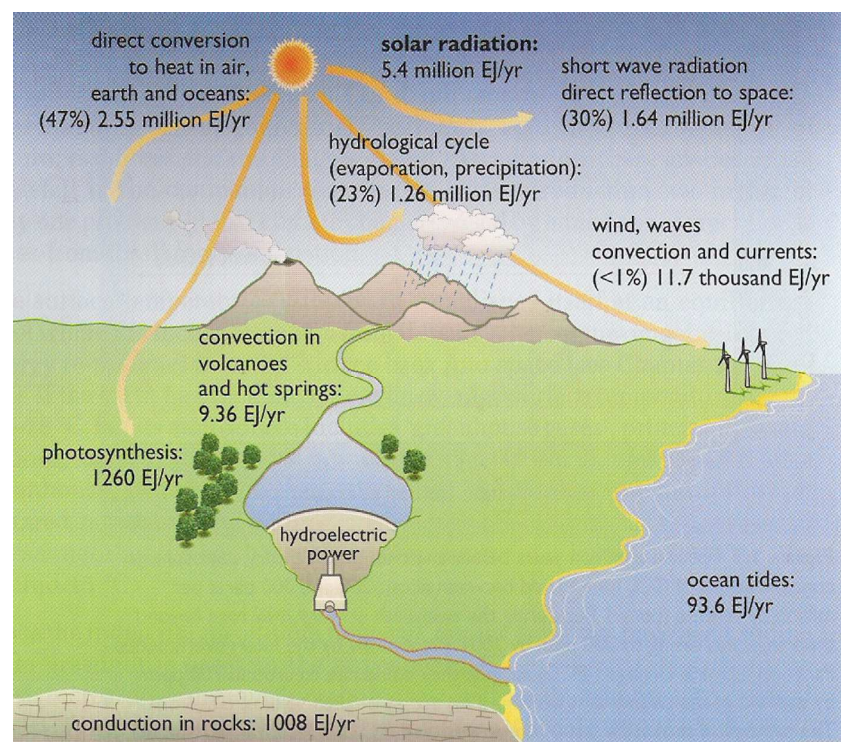

Figure 1. Renewable energy resource origins of the world and their extent [1].

Besides hydroelectric energy, other renewable energy resources are intensely worked on in parallel with the ever-developing environmental conscience and their non-depleting nature as sources. For today, higher investment costs compared with fossil fuels keep their share low in the general energy consumption. But decreasing costs in this high potential area via technological developments to generate energy from solar radiation that is the source of renewable energies, either directly or via transformation.

Solar radiation can be directly transformed into usable energy via different technologies. Solar radiation can be absorbed by "collectors" to heat water or spaces. Furthermore, buildings can be designed in a suitable manner to utilize solar energy in heating and lighting needs. At the same time, solar energy can be intensified via mirrors to obtain high degrees of heat to generate electricity. It is known that such solar thermal electricity power stations that work via this principle are used in commercial activities. Solar radiation can be directly transformed into electricity via photovoltaic (PV) modules. Photovoltaic cells can generally be mounted on the frontal facades and roofs of buildings. The electricity obtained from photovoltaic cells is currently expensive, but they are becoming more widespread as their prices decline.

Solar radiation can be transformed into utilizable energies indirectly via other energy types. Principally, a large portion of solar radiation is absorbed by the oceans, and some of it reaches the land portion of the world. Examples for indirect usages of solar energy are wind energy, biomass energies, wave energy etc.

Along with this, there are two other renewable energy sources that are not associated with solar radiation. These are tide and geothermal energies. Tide energy is usually confused with the wave energy. But their origins are completely different. Tide energy is utilized by holding rising waters and later setting low barriers or dams. In tide energy, there are low barriers or dams that hold the rising waters and direct them towards turbines that generate electricity. Besides these, it is possible to utilize strong underwater electricity current power as well. In order to utilize this energy source, there are many tools such as sea electricity flow turbine on the frontline. The heat inside the earth is the geothermal energy resource. Actually the high heat occurring in the earth is due to gravity. Besides this, radioactive materials that are spread in the core of the earth since the very early times were used to obtain heat. Some locations with proximate hot stones near the surface may heat up the underground waters. This phenomenon has been used for centuries to obtain hot water and steam. In some countries, geothermal steam is used to generate electricity or the hot water from these sources are used for heating purposes. Along with this, if steam or hot water is excavated in large quantities, and the turned rocks create heat, the geothermal locations may start to cool down and new holes may emerge in close proximities. If such a thing occurs, geothermal source will not be renewable. But if the excavation rate of steam and hot water is lower than the renewal rate, it can be said that the source is renewable.

In summary, it can be said that renewable energy resources are largely among the prioritized energies in the world. In the second half of the 21 st century, renewable energy sources will comprise a much larger percentage of global energies and will attain the deserved place and importance.

\section{Developments in the Field of Energy}

\subsection{The Global Status}

The distribution of sources that are used to meet the primary energy consumption in the world are as follow; $33,1 \%$ by oil, $23,7 \%$ by natural gas; $30,3 \%$ by coal; $4,9 \%$ by nuclear, $6,4 \%$ by hydroelectric and $1,6 \%$ by other renewable sources [5]. As it can be seen by these data, the share of the energy types that are defined as renewable are at $8 \%$ levels, mostly due to hydroelectric. Thus, we can say that renewable energy sources are currently still insufficiently utilized in meeting the mankind's energy needs and there is still a great potential.

When hydroelectric energy and dams are considered; today we can see that only one third of the potential hydro-energy amounts are being utilized. This amount corresponds to $17 \%$ of the global energy generation. There are over $8500 \mathrm{MW}$ of installed capacity in power stations in 22 different countries, led by the United States, Philippines and New Zealand. Wood, on the other hand, has a significant potential as a renewable energy but is losing its "renewable" quality due to fast consumption. Today, 50 acres of forests are being consumed 
every minute. When we consider wind turbines with up to 5 MW of installed capacity, we can see that they are widely used in the United States, China, Germany, Spain and Denmark. In 2011, the energy generated by wind turbines exceeded 150 GW. While biomass and sea energy is considered to be the cleanest energy sources, their contribution to global scale generation is only at $1 \%$ levels [6].

The most important properties of renewable energy sources are lowering carbon dioxide emissions and contribute to preserving the environment. These sources are domestic resources, and contribute to decreasing import dependency in energy and increasing employment. Furthermore, they are receiving a wide and strong support from the public. In other words, renewable energy sources have all of the accessibility, existence, acceptability properties [6].

\subsection{Status in Turkey}

Regarding global consumption in primary energy, Turkey comprise only $0,95 \%$ of the global total. The distribution of this consumption with respect to energy sources are as follow: $26,7 \%$ by oil, $31,9 \%$ by natural gas, $16,6 \%$ by coal, $14,1 \%$ by lignite, $4,1 \%$ by hydroelectric, $4,2 \%$ by wood and garbage and $2,4 \%$ by other renewable energy sources [5]. In this case, it can be observed that fossil fuels have an $89 \%$ weight in total consumption.

When the primary energy resource generation and consumption in Turkey is considered on an annual basis; while certain improvements are observed in both variables, we can easily conclude that generation does not fully cover consumption. While in $1970,76,9 \%$ of the consumption of energy sources were met by domestic sources, this rate declined to $25 \%$ in out day. In other words, $75 \%$ of the energy consumption in Turkey is foreign sourced and this rate will increase further unless developments are made in increasing energy investments and energy sources are diversified [7]. Besides this, the utilized energy sources are those that cause the most $\mathrm{CO} 2$ emission from an environmentalist perspective. Therefore, works towards renewable, environment friendly and high-potential energy sources and technologies continuously gain importance. Water, solar and wind energies are the leading among those [8].

The gross hydroelectric energy potential in Turkey is defined to be 433 billion $\mathrm{kWh} /$ year. The gross hydroelectric energy potential that can be technically utilized is estimated to be 216 billion $\mathrm{kWh} /$ year [2]. There are opinions that state the economically utilizable hydro potential in Turkey to be higher than the officially accepted 125 billion $\mathrm{kWh} /$ year, to be around 160-180 billion $\mathrm{kWh} /$ year. But considering that we currently utilize around one third of even the officially accepted 125 billion $\mathrm{kWh} /$ year, the need to utilize the local, cheap, clean and renewable hydroelectric resources in much higher rates to meet the country's energy demand can be clearly observed [2].

The economic wind power potential of Turkey is calculated to be approximately $83.000 \mathrm{MW}$. The energy generation potential is being stated to be $166 \mathrm{TWh} /$ year [9]. According to the data from TMMOB Chamber of Electrical Engineers, the cost of electricity generated in wind power plants is between 4 and $6 \$$ cent $/ \mathrm{kWh}[10]$. In parts of our country with high wind potential, the unit cost of wind energy can decline to 3-4 $\$ c e n t / \mathrm{kWh}$ [11]. These data show that through advanced technology, wind power plants have a higher competitive opportunity with other resources [10].

Regarding geothermal energy, Turkey has the 7th largest potential in the world [12]. The theoretical geothermal potential of the country is stated to be $31.500 \mathrm{MW}$ [13]. On the contrary, there are those who claim this data is not scientific [14]. When the entire geothermal energy potential of Turkey is considered; it was announced by International Geothermal Association European Desk that it will contribute 20 billion dollars of net added value to the national economy per year.

Although currently generating electricity via solar energy seems to be comparatively more expensive, there is rapid development regarding the productivity of photovoltaic cells. All regions in Turkey have a satisfactory level regarding solar energy potential and it can be stated that they are all well above most of the EU countries. Still, the share of solar energy in total energy consumption is around low levels of $0.6 \%$.

Within the scope of biomass energy, three main fuels, namely bioethanol, biodiesel and biogas can be obtained. But the bioethanol and biodiesel efforts in Turkey are in very limited levels and no significant development was recorded thus far. In biogas, there are generation activities in the waste yards of certain cities and in some industrial facilities and in the waste water facilities of some municipalities. Furthermore, by making the needed investments, there is a potential to obtain biogas from animal wastes in our country [15].

Table 1. The Renewable Energy Resource Potential of Turkey [16].

\begin{tabular}{llll}
\hline $\begin{array}{l}\text { Renewable Energy } \\
\text { Resources }\end{array}$ & Gross (MW) & $\begin{array}{l}\text { Technical } \\
(\mathbf{M W})\end{array}$ & $\begin{array}{l}\text { Economical } \\
\text { (MW) }\end{array}$ \\
\hline $\begin{array}{l}\text { Solar Energy } \\
\text { Hydroelectric Energy }\end{array}$ & 111500000 & 1400000 & 116000 \\
Wind Energy & 500 & 53750 & 34862 \\
$\begin{array}{l}\text { Terrestrial (Electricity) } \\
\text { Nautical (Electricity) }\end{array}$ & 220000 & 55000 & 20000 \\
Geothermal Energy & - & 60000 & - \\
$\begin{array}{l}\text { Heating } \\
\text { Electricity }\end{array}$ & 31500 & 7500 & 2843 \\
Biomass Energy & 4500 & 500 & 350 \\
Classic (Mtep/year) & 30 & 10 & 7 \\
Modern (Mtep/year) & 90 & 40 & 25 \\
Wave Energy (Electricity) & 75000 & 9000 & - \\
\hline
\end{tabular}

The gross, technical and economical energy potentials of renewable energy sources in Turkey are summarized in Table 1. As can be seen from the table, solar energy emerges as the largest renewable energy. Thus, from an economic perspective, the economic energy potential of solar energy has a value of 116.000 MW, followed by hydroelectric energy with 34.862 MW value. Wind energy has the third rank in economic generation potential with $20.000 \mathrm{MW}$ potential generation value, which correspond to the wind energy that can be 
obtained from the terrestrial area. The wind energy potential from the nautical area is considered to be at least as much as the potential in the terrestrial area.

As it can be understood from the chart, geothermal energy has the third rank among renewable energy sources. With 3.200 MW of economic potential, a major part of this energy potential $(2.843 \mathrm{MW})$ is applicable for heat energy generation. As it is in the entire world, we have an economic potential of 32 MW regarding biomass energy generation that can be accepted for our country. On the other hand, the wave energy that is not currently utilized in our country but comprises a strong renewable energy sources potential has a 9.000 MW potential energy power. The mentioned energy represents a potential that is usable in direct electricity generation.

\section{Discussion}

Among the countries, there is a definite competition to develop technologies, and in accordance with this, technologies are being constantly developed. The main strength of countries in developing technologies is the accumulation of knowledge, but the primary element that supports it is energy. In principle, today, the development levels of countries are being measured in association with their energy consumption. Within this framework, while USA is over 6 TEP (ton equivalent petroleum), West Europa is around 3-6 TEP consumption while Turkey has a consumption level as low as 1,5-3 TEP [17]. Efforts to elevate Turkey from a developing country status to a developed country status make an increase in per capita energy consumption inevitable.

Increasing per capita energy consumption will be based on either fossil fuels or on renewable energy sources. The period of finite energy sources such as coal, oil, natural gas is expected not to last very long, therefore directing towards renewable energy sources becomes a necessity. In principle, there had been an age of coal, followed by an age of oil. Today, a painful transition to the natural gas age is being experienced. Besides the distribution of natural gas in the global geography and supply security issues, it is known that there are problems regarding the safety of gas transmission systems. In this context, its sustainability is in question. On the contrary of natural gas being widespread globally, there is an important barrier such as climate change that challenges all fossil based energy sources. The utilization of renewable energy sources that provide domestic solutions to energy needs requires to increase in Turkey, as well as in all developed countries. In this context, it is beneficial to handle the topic by stating that Turkey's utilization of renewable energy sources is very insufficient. When utilization of renewable energy sources in the country is observed, it can be seen that a very low portion of the renewable energy potential it has is being utilized. For example, only $21 \%$ of the technical hydroelectric potential of the country has been utilized so far. This ratio is $86 \%$ in USA and $56 \%$ in Canada. Similarly, only $4.2 \%$ of the solar energy potential in the country, which represents a very significant potential, is currently being utilized. And of this, $0.5 \%$ is utilized for electricity and $3.6 \%$ is utilized for heat generation purposes. On the other hand, only $3 \%$ of the terrestrial wind power potential is being utilized in generation. Primarily, this rate was attained through large investment initiatives in the recent period. This rate is $22.4 \%$ in Denmark and $27 \%$ in Spain. Germany has an installed capacity of wind power plants that is above its technical potential. The nautical power potential of Turkey exceeds its terrestrial potential and currently it is not utilized at all. On the other hand, although the country has a very advantageous position with respect to geothermal energy resources, even the real potential has not even been revealed yet. The limited data on hand shows that between $\% 0,6$ and $\% 6.2$ of this potential can be transmitted to electricity and $\% 2,5$ and $\% 21,6$ of it can be transmitted to thermal in generation. In biomass, only 0.008 of the country's potential is being utilized, including all bio-fuels. There is currently no generation in the country with respect to wave energy.

\section{Conclusions}

In order to increase the rates of using renewable energy potential in Turkey from these lows to much higher levels, it is necessary to give the required emphasis on this area. In reality, Turkey is a "Renewable Energy Heaven" as it has almost all of the renewable energy sources. The responsibility of the citizens of this country is to find ways to integrate these valuable resources into generation in the right manner.

The fact that Turkey has most of the renewable energy sources and has high potentials in each of them provides the country with the opportunity to easily facilitate energy diversity. But at this point, making a move to facilitate high values of investments in all renewable energy sources is not economically feasible. Therefore, a balanced and staged strategy that emphasizes the resources that are prioritized for the country but does not ignore the rest of the resources should be adopted. Within this frame, the wind energy capacity should be increased via necessary legal regulations during the first stage. Within the same frame, the hydro energy and geothermal heat capacities can be increased as well. Again, solely via legal regulations, the usage of modern technologies in solar energy and integration of these in heating systems should be incentivized. Thus, only via legal precautions, significant initiatives and increases in utilizing hydro energy, geothermal heat and solar thermal energy can be established. State incentives in Photovoltaic cells should be continued. Following these regulations, investments towards geothermal electricity generation should be initiated in the second stage. After recording a significant development in utilization rates of hydro, wind, geothermal and solar energy potentials, efforts towards increasing the utilization rates for wave energy and controlled biomass energy should be carried on during the third stage. Turkey should create a new "energy diversity strategy and policy" that keeps in mind the natural energy potentials the country has. This strategy should be planned to gradually relieve the country of import dependent fossil energy dilemma and to provide the economy with a sigh of relief. 
Today, we live in a world with large scale energy distribution networks and systems on fossil origin energy resources in line with the requirements. But the future will be an "age of renewable energy" where our energy needs will be met with local solutions. Within this frame, we need to create our local solutions and relevant infrastructures.

\section{References}

[1] Boyle G. Renewable Energy Power for a Sustainable Future. Oxford University Press Oxford. Glasgow; 2004.

[2] Pamir AN. Dünyada ve Türkiye'de Enerji. Türkiye'nin Enerji Kaynakları ve Enerji Politikaları, Metalurji Dergisi. Web-based database:

〈http://www.metalurji.org.tr/dergi/dergi134/d134_73100.pdf〉 (last visited 05.02.14); 2003.

[3] Twidell JW, Weir AD. Renewable Energy Resources. New York: Taylor \& Francis; 2006.

[4] Sorensen B. Renewable energy focus handbook. Academic press is an imprint of Elsevier. San Diego; 2009.

[5] Türkyılmaz O, Özgiresun C. Türkiye'nin Enerji Görünümü. Chamber of Mechanical Engineers. Web-based database: 〈http://www.mmo.org.tr/resimler/dosya_ekler/dd924b618b4d6 92_ek.pdf) (last visited 01.02.14); 2012.

[6] Özkaya SY. Yenilenebilir Enerji Kaynakları, Gen Bilim Türkiye Bilim Sitesi. Web-based database: 〈http://www.genbilim.com/content/view/3976/89/〉 (last visited 05.01.10); 2008.

[7] Vardar A. Rüzgar Enerjisi ve Tarımsal Uygulamaları (Seminer Notları). In: Çanakkale Tarım İl Müdürlüğü, Çanakkale; 30 October 2009.
[8] Balku Ș. Enerji, Çevre ve Rüzgar Türbinleri. In: International Conference on Global Climate Change and Environmental Impacts, Konya; 18-20 October 2007.

[9] Van Wijk AJM, Coelingh JP. OECD countries wind potential. Utrect: Utrecht University; 1993.

[10] TMMOB. Enerji Raporu. In: Elektrik Mühendisleri Odas1 38. Olağan Genel Kurulu, Ankara; 27-28 April 2003.

[11] Vardar A, Çetin B. Cost Assessment of the Possibility of Using Three Types of Wind Turbine in Turkey. Energy Exploration \& Exlpoitation 2007; 25 (1): 71-82.

[12] Koç E, Şenel MC. Dünyada ve Türkiye'de Enerji Durumu Genel Değerlendirme. Mühendis ve Makina, 2013; 639: 32-44.

[13] MTA. Maden Tetkik ve Arama Genel Müdürlüğü. Web-based database: 〈http://www.mta.gov.tr/v2.0/index.php〉 (last visited 24.02.14); 2014.

[14] Satman A. Türkiye'nin Jeotermal Enerji Potansiyeli. In: İTÜ Enerji Enstitüsü Semineri, İstanbul; 23 March 2007.

[15] MMO. Türkiye'nin Enerji Görünümü. TMMOB Makina Mühendisleri Odas1. 2012; 588.

[16] Ültanır MÖ. Renewable Energy Sources in Turkey. Energy 1998; Special Issue: 44-47.

[17] BP. Primary energy consumption per capita 2012 (Tonnes oil equivalent). Web-based database: 〈http://www.bp.com/en/global/corporate/about-bp/energy-eco nomics/statistical-review-of-world-energy-2013/review-by-en ergy-type/primary-energy.html2013〉 (last visited 12.01.14); 2013. 